LA-7750

AFATL-TR-79-S

Studies of Long-Term Ecological

Effects of Exposure to Uranium IV

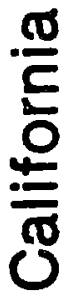

世

?

Ф

론

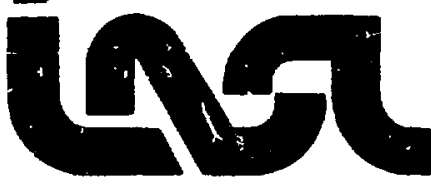




\title{
Studies of Long-Term Ecological Effects of Exposure to Uranium IV
}

\author{
Gary C. White \\ Ernest S. Gladney \\ Kenneth V. Bostick \\ Wayne C. Hanson*
}

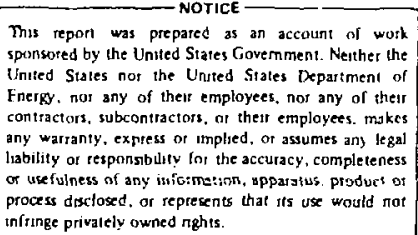

"Battelle Pacific Northwest Laboratories, Ecosystems Department, 6652 I Building. Area 600, P.O. Box 999, Richland, WIA 99352. 


\begin{tabular}{|c|c|}
\hline REPORT DOCUMENTATION PAGE & $\begin{array}{l}\text { READ INSTRUCTIONS } \\
\text { BEFORE COMPLETING FORM }\end{array}$ \\
\hline \begin{tabular}{l|l} 
AEPONT AUMAET & GOVT ACCESSIONNO \\
AFATL-TK- $79-9$ &
\end{tabular} & 3 RECIDIENT'S CATALOG NUMEEA \\
\hline TITLE (end Subitito) & $\begin{array}{l}3 \text { TYOE OF REPORT DEFIDO COVEUEO } \\
\text { Final RepOTt } \\
1 \text { Oct } 77-30 \text { Sep } 78\end{array}$ \\
\hline & $\begin{array}{l}\text { LEAFOAMING OAG. REPOAT NUMEER } \\
\text { LA-7750 }\end{array}$ \\
\hline $\begin{array}{l}\text { Gary C. White, Ernest S. Gladney, Kenneth V. } \\
\text { Bostick, Wayne C. Hanson }\end{array}$ & $\begin{array}{l}\text { CONTARCT OR GARNT NUMBEA(A) } \\
\text { Project Order ATL-8-205 }\end{array}$ \\
\hline $\begin{array}{l}\text { DER JAMING ORGANIZATION NAME ANO AODQRESS } \\
\text { Envi rDnmental Science Group (H-12) } \\
\text { LOS Alamos Scientific Laboratory, P.o. BOX } 1663 \\
\text { LOS Alamos, NM } 87545\end{array}$ & $\begin{array}{l}\text { 16. PROGRAM ELEMENT. PROJECT, TASK } \\
\text { AREA A WORK UNIT NUMEES } \\
\text { PrOgram Element } 62602 \mathrm{~F} \\
\text { JON O6CD0102 }\end{array}$ \\
\hline $\begin{array}{l}\text { " COMTROLLING OFFICE NAME AND ADDAESS } \\
\text { ADTr/DLV }\end{array}$ & $\begin{array}{l}\text { 12. PEPOAT DATE } \\
\text { MaY, } 1979\end{array}$ \\
\hline Eglin AFB FL 32542 & $\begin{array}{l}13 \text { NUMBER OF PAGES } \\
20\end{array}$ \\
\hline TA MON TORING GGENCY NGME A ACDAESSIII dilferent from Controllind Olfice) & $\begin{array}{l}\text { 15. SECUAITY CLASS. (of th/ roport) } \\
\text { Unclassified }\end{array}$ \\
\hline & $\begin{array}{l}\text { 150 DECLASSIFICATION DOWNGAADING } \\
\text { SCHEDULE }\end{array}$ \\
\hline $\begin{array}{l}15 \text { DISTAIDUTION STATEMENT (ol thr Roporl) } \\
\text { Approved for Public Release; Distribution Unlimite }\end{array}$ & \\
\hline 7 DISTRIBUTION STATEMENT for tho mbeteract enterod in Blach 20 , If different fro & Reports \\
\hline 18. SUPPLEMENTAAY NOTES & \\
\hline $\begin{array}{l}\text { 19. KEY wohas (Continue on reverse aldo lt nocosary and identliy by block number) } \\
\text { Uranium, Depleted Uranium, Uranium Analysis, Phosw } \\
\text { Instrument, Epithermal Neutron Activation, Delayed }\end{array}$ & $\begin{array}{l}\text { ich Portable Survey } \\
\text { Neutron Activation }\end{array}$ \\
\hline 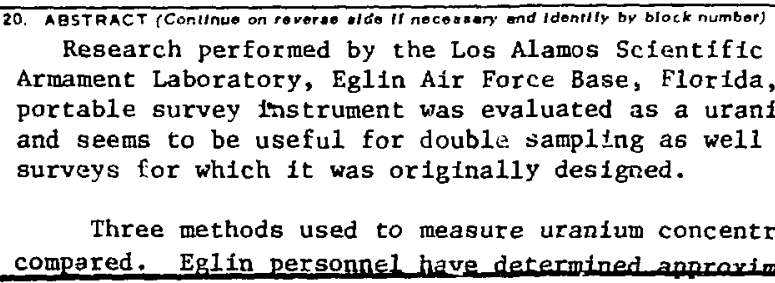 & $\begin{array}{l}\text { Laboratory for the Alr Force } \\
\text { is reported. The phoswich } \\
\text { am field-survey lnstrument } \\
\text { as for the quick field } \\
\text { at ions in solis were also }\end{array}$ \\
\hline
\end{tabular}




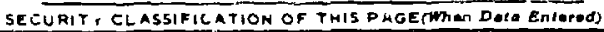

analyzing scils in an ND-100 gamma counter. Thermal-neitron-1nduced delayed neutron activation and instrumental eplthermal neutron activation analysis are the methods used at the Los Alamos Scientific Laboratory, Comparisun of the three analytical techniques indicates differences; only part of the lack of agreement is explainable by the heterogeneity of aliquots taken from the same soll sample. There seems to be a baslc difference in what each of the three techniques measures. 
CONTENTS

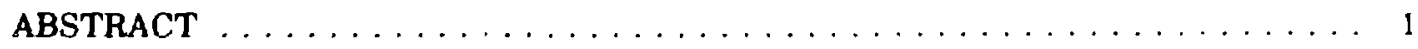

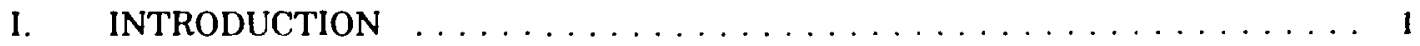

II. EVALUATION OF THE PHOSWICH PORTABLE SURVEY INSTRUMENT . . . 2

III. ANALYTICAL PROCEDURES DEVELOPMENT FOR DETERMINATION OF

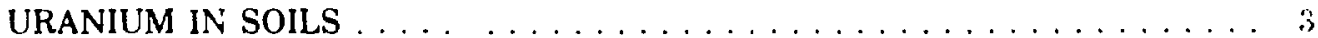

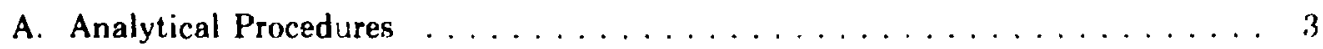

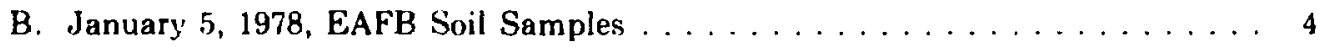

C. May 5,1978 , EAFB Soil Samples $\ldots \ldots \ldots \ldots \ldots \ldots \ldots \ldots \ldots$

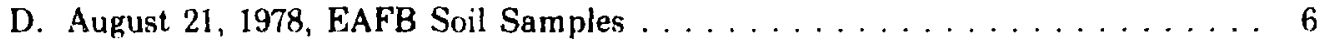

IV. SUMMAKY AND CONCLUSIONS $\ldots \ldots \ldots \ldots \ldots \ldots$

ACKNOWLEDGMENTS $\ldots \ldots \ldots \ldots \ldots \ldots \ldots \ldots \ldots$

REFERENCES $\ldots \ldots \ldots \ldots \ldots \ldots \ldots \ldots \ldots \ldots \ldots \ldots \ldots \ldots \ldots$

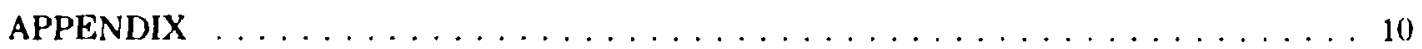

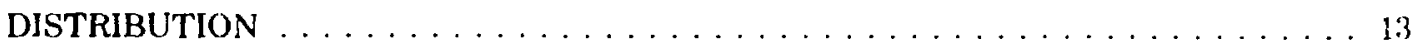




\title{
STUDIES OF LONG-TERM ECOLOGICAL EFFECTS OF EXPOSURE TO URANIUM IV
}

by

Gary C. White, Ernest S. Gladney,

Kenteth V. Bostick, and Wayne C. Hanson

\begin{abstract}
Research performed by the Los Alamos Scientific Laboratory for the Air Force Armament Laboratory, Eglin Air Force Base, Florida, is reported. The phoswich portable survey instrument was evaluated as a uranium fieldsurvey instrument and seems to be useful for double sampling as well as for the quick field surveys for which it was originally designed.

Three methods used to measure uranium concentrations in soils were also compared. Eg,lin personnel have determined approximate concentrations by analyzing soils in an ND-100 gamma counter. Thermal-neutron-induced delayed neutron activation and instrumental epithermal neutron astivation analysis are the methoc's used at the Los Alamos Scientific Laboratory. Comparison of the three analytical techniques indicates differencos; owly part of the iack of agreement is explainable by the heterogeneity of aliquote taken from the same soil sample. There seems to by a basic difference in what cach of the three techniques measures.
\end{abstract}

\section{INTRODUCTION}

This report summarizes results from October 1 , 1977 , through September 30, 1978, of reeearch performed by the Los Alamos Scientific Laboratory (LASL) for the Air Force Armament Laboratory, Eglin Air Force Base (EAFB), Florida. Included are (1) an evaluation of the phoswich portable survey instrument as a uranium field-survey instrument, (2) analytical results from three sets of soil samples from test ranges at EAFB; and (3) a comparison of three different analytical techniques used for uranium determinations.
The general scope and objectives of this study and the site descriptions were presented in the 1976 and 1977 completion reports. ${ }^{1-8}$ Objectives of the research efforts reported here were:

(1) to determine if the phoswich portable survey instrument is useful for in situ measurement of uraniv'in in soil, and

(2) to evaluate three analytical techniques currently used to determine uranium concentrations in soil.

This research has application to field situations where substantial amounts of uranium have been released to the environs. 


\section{EVAIUATION OF THE PHOSWICH PORTABLE SURVEY INSTRUMENT}

The standard instrument for the field detection of low-energy photons sucl: as those emitted from uranium has been the FIDLER (Field Instrument for the Detection of Low-Energy Radiation). However, Compton events from high-energy photons are a major source of detector background and place relatively high limits on the detectability of low. energy events.

We are pursuing a possible solution to this problem by using a phoswich low-energy photon detector, which is designed to compensate for higherergy photon interference (Fig. 1). The phoswich detector is composed of a sandwich of two different scintillator crystals coupled to a sinele photomultiplier tube. Because of differences in the absorption characteristics of the two crystals, it is possible to differentiate between desired low-energy

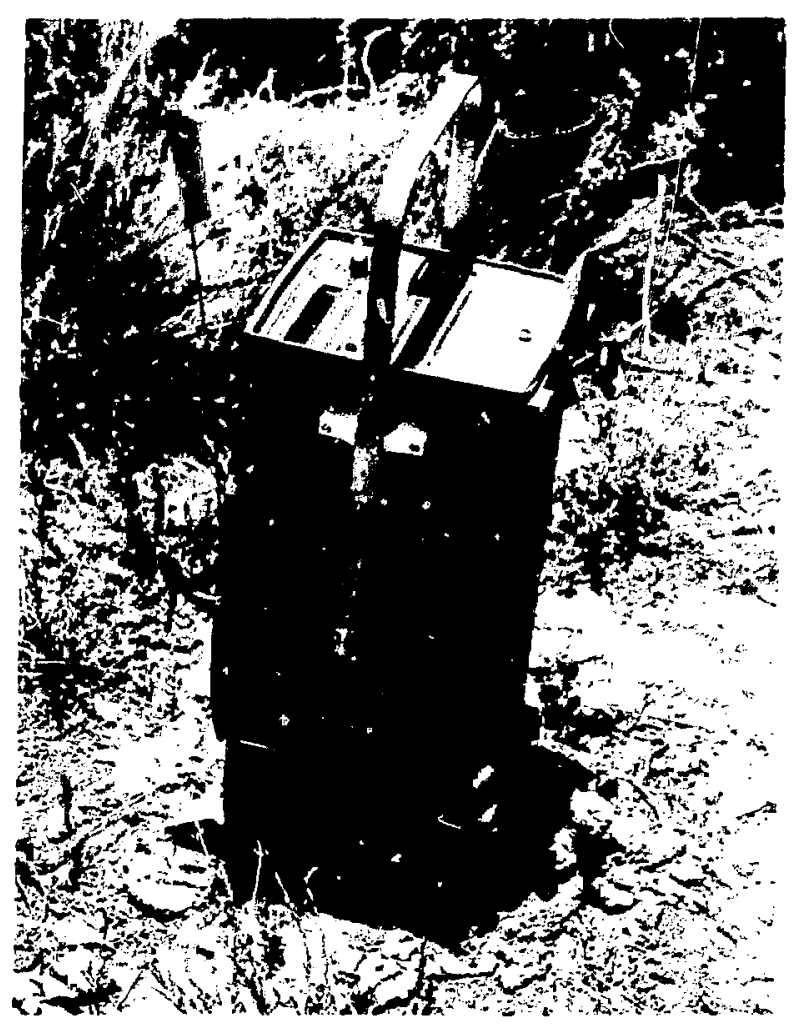

Fig. 1.

The phoswich portable survey instrument, which measures 30 by 8 by $8 \mathrm{~cm}$ and weighs 3 kg. events that stop only in the front thin crystal and thesse events, though similar in energy, that arise through other processes (such as Compton scattering; and leposit energy in both crystale. The detector used in this work has a NaI(Tl) crystal face, $1 \mathrm{~mm}$ thick, and a $\mathrm{CsI}(\mathrm{Na})$ back, $38 \mathrm{~mm}$ thick. The detector has a face surface area of $9216 \mathrm{~mm} \mathrm{~m}^{2}$, and thus integrates over this area. The instrument emits an audible "beep" for each photon absorbud only in the Nal portion of the detector. The frequency, or pitch, of the beep is a function of the count rate, hence facilitating qualitative surveys without constant operator attention to the count-rate neter or digital readout.

The E-F Firing Site at LASL was resampled with the phoswich survey instrument at the same locations that were sampled in the 1976 soil urs nium field survey. ${ }^{2}$ The initial sampling grid was systematically placed on a polar coordinate system radiating from the detonation point every $45^{\circ}$, with concentric circles at $10,20,30,40$, and $50 \mathrm{~m}$ from the detonation point. Count time for the phoswich was $500 \mathrm{~s}$, and background was determined from an in. contaminated soil sample from the same soil tyfe.

Soil samples collected on the grid system during the 1976 uranium survey at E-F Site were obtain $2 d$ with a polyvinylchloride coring tube with a $2.5-\mathrm{cm}$ inside diameter. Uranium concentrations were determined by fluorometric analysis. ${ }^{\text {a- }}$

The correlation between the phoswich measuraments and the uranium concentrations in the $0-0$ $2.5-\mathrm{cm}$-depth soil samples taken in $: 976$ was excellent (Fig. 2), with $\mathrm{I}=0 . \subseteq 5$ ( $\mathrm{P}<0,0001$ ) even thouk $\mathrm{h}$ the respective measurements were taken 2 yea:s apart. Changes in the distribution of uranium during the interval between samplings must have ber: $n$ minor relat: e to the total inventory of uranium in the soil.

One practical application of the relationship between the phoswich counts and the uranium concentration in the suil cores is in double sampling" to reduce the cost of a field survey. Field measucements of uranium with the phoswich survey inst rument are less expensive than those obtained by the collection and subsequent analysis of samples by chemical methods. Thus, a less expensive and leibor intensive sampling scheme can be developed by taking a large number $\left(n^{\prime}\right)$ of phoswich counts $\left(k_{1}\right.$, ivith mean $\bar{X}$ ) along with a much smaller number of sam. ples $(n)$ where both soil cores $\left(y_{t}\right)$ and phosipich 


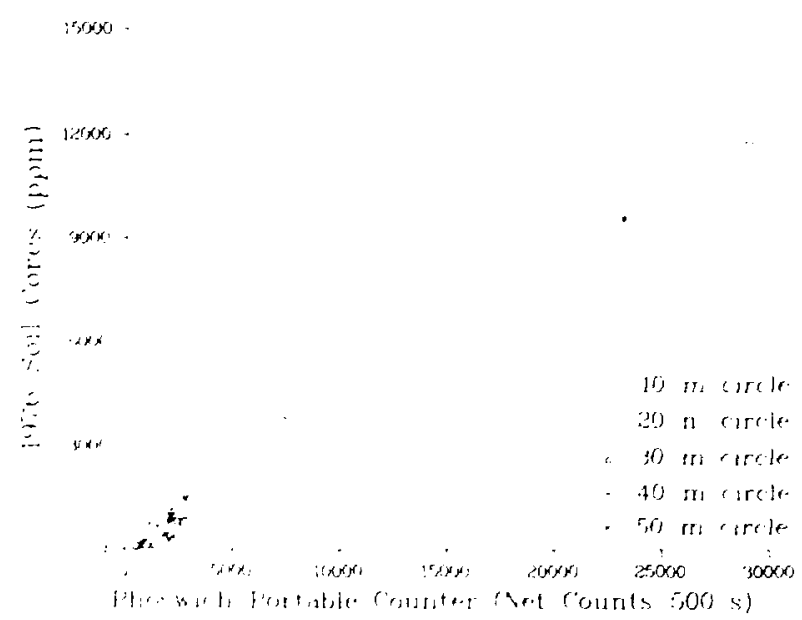

Fig. 2.

Uranium concentrations in the 0 - to $2.5-\mathrm{cm}$ depth segment from the 1976 E.F Site soil survey plotted with the 1978 phoswich portable survey instrument results.

counts are made. The phoswich counts are termed an auxiliary variable, because they are less expensive (1) acquire.) The phoswich counts are then used (c) make a regression estimate of $\bar{Y}$, or the mean uranium concentration, with regression coefficient B.

Assume as a model,

$y_{1}=\bar{Y}+B\left(x_{1}-\bar{X}\right)+e_{1}$

where, for fixed $x_{1}$, the random variate $e_{1}$ follows a frequency distribution with mean 0 and variance $S_{\mathrm{e}}^{2}$ $=S_{y}^{2}\left(1-\rho^{2}\right)$. Here, $S_{e}^{2}$ is the variance of $e_{1}, S_{y}^{2}$ is the variance of $\mathrm{y}_{1}$, and $\rho^{2}$ is the squared correlation coefficient of the $y_{1}$ and $x_{1}$.

In the ahove equation, a nonzero intercept was as sumed because the phoswich instrument may measure other radionuclides present at background levels. Thus, we do not want to assume that a plot of uranium concentration versus phoswich counts passes through the origin until this assumption has been tested with the data. Additionally, we assumed that a linear relation exists over the range of soil concentrations encountered. At very high uranium concentrations, the phoswich counter may not record counts fast enough to provide an accurate reading. Such concentrations are not expected in soil samples.
The regression estimate of mean uranium concentration is

$\hat{y}_{e}=\bar{y}+b\left(\bar{x}^{\prime}-\bar{x}\right)$,

where $\ddot{x}^{\prime}$ and $\bar{x}$ are the means of $x_{1}$ in the first and second samples, respectively, and $b$ is the lesst squares regression coefficient of $y_{1}$ on $x_{1}$, computed from the second sample. We are interested here in assessing the validity of the linear regression relating uranium concentration to the phoswich counts. The regression line fitted to the data in Fig. 2 is

$y_{1}=-71.57+0.3963 x_{1}+e_{1}$.

The intercept in the above eruation is not significantly different from zero $(P=0.33)$, indicating that a regression through the origin is adequate.

An important question is whether the data from E-F Site used to construct this regression equation are adequate for EAFB uranium contamination areas. Soil uranium concentrations at EAFB are much lower than those observed at E-F Site and are mostly due to depleted uranium on those test ranges of greatest interest. Also much of the observed correlation of the phoswich counts and soil cores in Fig. 2 is due to the four samples with high uranium concentrations. The rest of the samples seem to have much more scatter relative to the range in concentrations. Thus, more data need to be collected at the concentration levels observed at EAFB.

, possible drewback of the phoswich field instrument is that its response seems to be a function of air temperature; that is, the counting efficiency of the instrument is slightly affected by the ambient air temperature. We have in itiated studies in an environmental chamber to calibrate the instrumen"'s counts as a function of ambient temperature.

\section{ANAL YTICAL PROCEDURES DEVELOP. MENT FOR DETERMINATION OF URANIUM IN SOILS}

\section{A. Analytical Procedures}

Analytical results for three sets of EAFB soil samples are presented in the Appendix as Tables A-I, AII, and A-III. The samples were collected by EAFB 
personnel as a part of test range cleanup operations or other activities. Our interpretation is limited to the analytical characteristics of the data.

Three methods have 'een used to measure uraniums concentration in ec 1 . EAFB personnel have determined approximate concentrations by onalysis in an ND-100 gamma counter" (denoted as "EAFB method" in this report). Thermal-neutron-induced delayed neutron activation (DNA) and instrumental epithermal neutron activation analysis (IENA) were the methods used at LASL. Two-gram aliquots of EAFB soil samples were randomly selected and submitted for IENA and DNA analyses.",10 We have taken the following brief descriptions of these methods from Hanson and Miera.

In the IENA analysis, samples were first irradiated for $2 \mathrm{~min}$ with epithermal neutrons in the energy range 280 to $1000 \mathrm{eV}$. After a decay time of 2 to 4 days, each sample was counted for $5 \mathrm{~min}$ on a large $\mathrm{Ge}(\mathrm{Li})$ detector. The 228 - and $278-\mathrm{keV}$ transitions from the decay of ${ }^{290} \mathrm{~Np}$ (half-life 2.35 days) were observed and used for quantitative analysis. The gamma-ray spectra were accumulated on a pulse-height analyze1 and output on computercompatible magnetic tape for off-line data reduction. International Atomic Energy Agency (IAEA) soils with certified uranium concentrations were used to standardize the analyses.

DNA measurements were performed on each sample by irradiating the sample for $20 \mathrm{~s}$ in a thermalneutron flux. Irradiations were made at different reactor power levels, but for each, the thermalneutron flux was monitored during the exposure by a fission ion chamber. The sample was pneumatically transferred to a neutron counter of $27 \%$ efficiency and counted for $20 \mathrm{~s}$ following a $10-\mathrm{s}$ delay. The neutron data were normalized to a constant flux. The system was calibrated to samples of NBS SRM1633 (fly ash) of certified uranium concentration. Uranium concentrations were calculated with the assumption that the ${ }^{280} \mathrm{U}$ was in normal crustal abundance.

IENA measured only ${ }^{28} U$. However, for uranium occurring in crustal abundance, ${ }^{280} \mathrm{U}$ makes up $99.3 \%$ of the total uranium present. In contrast, DNA measures only ${ }^{288} \mathrm{U}$, which makes up $0.7 \%$ of crustal abundance. Therefore, when measuring uranium depleted in ${ }^{288} \mathrm{U}$, the DNA method seriously

*Nuclear Data, Inc., Schaumberg, IL 60172. underestimates the total uranium in the sample. However, the ratio of the uranium concentrations obtained by the two methods (DNA/IENA) is useful to indicate the presence of depleted or enriched uranium. This ratio should equal 1 if no depleted or enriched uranium is present.

\section{B. January 5, 1978, EAFB Soil Samples}

The data in Table A-I were obtained from seven soil samples collected on the Air Force Development and Test Center (ADTC) Range 74-L on 5 January 1978 , and two control samples collected off the Range, LASL analyses were conducted on three 2-g aliquots taken from each sample. Control samples were analyzed by DNA and agree well with the Eglin gamma-counting method. The samples from ADTC Range 74-L were analyzed for uranium by IENA and the data agreement between laboratories is only fair. The instances of wide differences (samples 1-1, 1-7, and $2-2$ ) probably reflect aliquoting problems in a sample where the uranium is not well mixed.

\section{May 5, 1978, EAFB Soil Samples}

The data in Table A-II are from 34 soil samples collected 5 May 1978 on Range 74-L. LASL DNA analyses were conducted on three 2-g aliquots taken from each sample, but IENA analyses were conducted on only one 2-g aliquot. Summary statistics and correlations between the three different analyses are presented in Table I, and the data are plotted in Figs. 3-5.

The correlations in Table I are highly significant but do not test the hypothesis that any two methods are actually measuring the same thing. For example, suppose method $\mathrm{y}$ and method $\mathrm{x}$ are related by $\mathrm{y}=$ bx. If both $x$ and $y$ are observed without error, then the correlation between them is 1 . Likewise, suppose $y=a+x$. Again the correlation between $y$ and $x$ is 1 . In both cases, however, meth $d y$ and method $x$ s.re not measuring the same quarities, because the two concentrations differ by a constant multiplier or an additive constant.

All three figures suggest that the linear function relating the two plotted variables passes throug! 1 the origin, and this was further verified by linear rr:gression tests for nonzero intercepts. (That is, al' three 
TABLE I

SUMMARY STATISTICS AND CORRELATION MATRIX FOR THREE METHODS OF MEASURING URANIUM CONCENTRATION IN SOIL FROM 5 MAY 1978, RANGE 74-L SAMPLES

\begin{tabular}{|c|c|c|c|}
\hline Statistic & EAFB & IENA & DNA \\
\hline $\mathbf{n}$ & 34 & 34 & 34 \\
\hline Mean, $x$ & 80.7 & 55.4 & 12.2 \\
\hline Standard Deviation, $\mathrm{s}$ & 126.6 & 89.0 & 21.2 \\
\hline Coefficient of Variation, $\mathrm{s} / \overline{\mathbf{x}}$ & 1.6 & 1.6 & 1.7 \\
\hline Median & 22.0 & $10 !$ & 2.2 \\
\hline Minimum & 0.5 & 0.0 & 0.7 \\
\hline Maximum & 443 & 370 & 99 \\
\hline Range & 42.5 & 370 & 98.3 \\
\hline
\end{tabular}

\begin{tabular}{|c|c|c|}
\hline Methods & Correlation & Significunce \\
\hline EAFB with IENA & 0.90 & $<0.001$ \\
\hline EAFB with DNA & 0.94 & $<0.001$ \\
\hline IENA with DNA. & 0.92 & $<0.001$ \\
\hline
\end{tabular}

tests accepted the null hypothesis of zero intercepts.)

Note in Figs. 3-5 that the three methods appear to be measuring different quantities because the slope of a linear function through the origin is not 1 . We have compared the three seis of ratios (IENA/EAFB, DNA/EAFB, and IENA/DNA) against 1 with the Wilcoxon signed rank test ${ }^{11}$ as a means of statistically testing for differences in the three analytical methods. If each technique is measuring the same quantity, then the ratio of the two analyses for a particular sample should be close to 1 ; that is, $y_{t}=x_{1}$, or $y_{1} / x_{1}=1$. Because of randomness, the ratio wil not be exactly 1 , and thus a statistical procedure is required to determine if the ratio differs significantly from 1 . The Wilcoxon signed rank test provides the probability of observing a sample with as many values less than (or greater than) 1 , giving each value a weight based on its rank. For example, in Table II we see that for the ratio IENA/EAFB, 26 of the 34 samples were less than 1. If the expected ratio was really 1 , the probability of observing this many values less than 1 is 0.008 . Thus, we conclude that IENA and EAFB procedures are not measuring the same quantities.

Si-nilar results (but not statistically significant at $\mathrm{P}=0.05$ ) are observed ror DNA and EAFB. We ex-

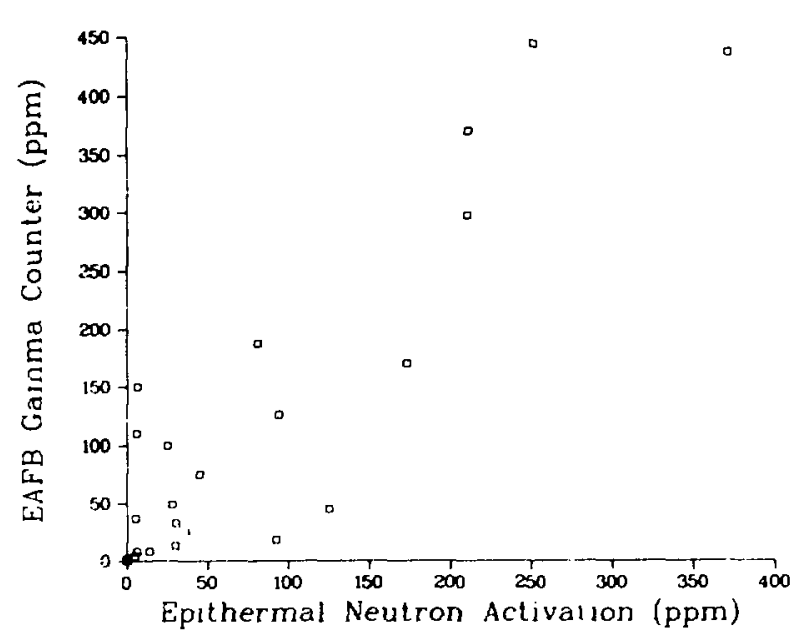

Fig. 3.

Results of the EAFB and IENA analytical techniques for determining uranium concentration in soil from the 5 May 1978, Range 74-L samples.

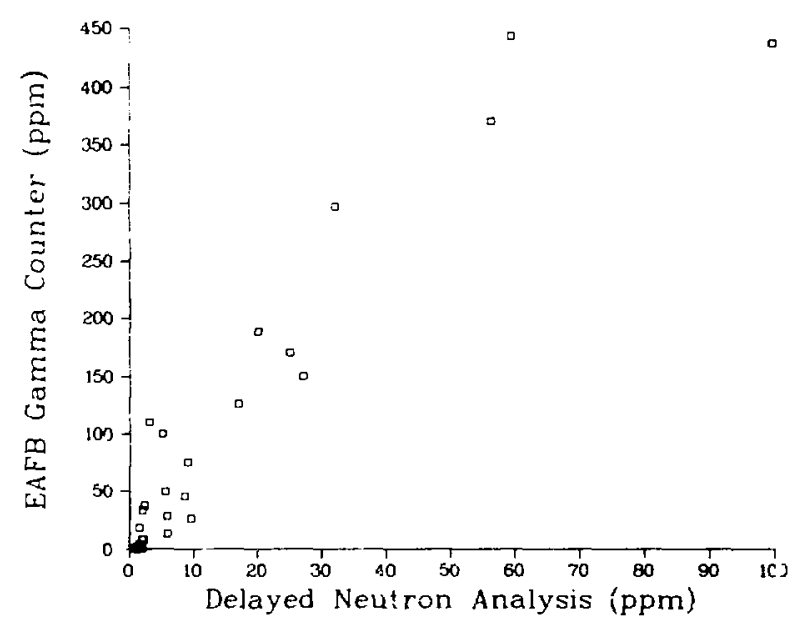

Fig. 4.

Results of the EAFB and DNA analytical techniques for determining uranium concentration in soil from the 5 May 1978, Range 74-L samples.

pected this because DNA measures only ${ }^{2 r s} \mathrm{U}$ and the Range 74-L soils are contaminated with depleted uranium.

The test also significantly rejected $(P=0.001)$ the null hypothesis for the IENA-DNA ratios. The mean of the IENA-DNA ratios was 5.1 ( $\mathrm{s}=10.6$ ), indicating that several of the samples had ratios much 
TABLE II

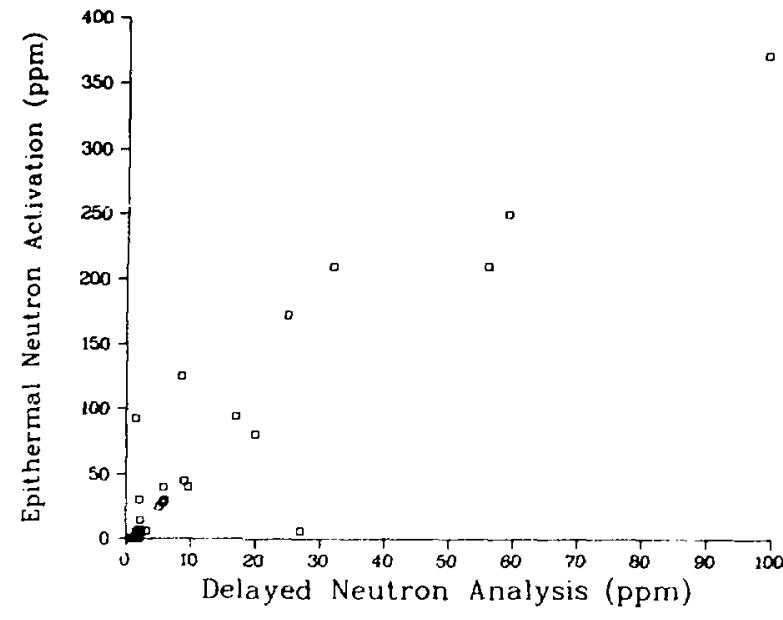

Fig. 5.

Resuits of the IENA and DNA analytical techniques for determining uranium concentrations in soil from the 5 May 1978, Kange 74-L samples.

greater than 1. As discussed above, the mean of the ratios of IENA to DNA should differ from 1 because DNA results are highly dependent on the isotopic ratio of ${ }^{283} \mathrm{U}$ to ${ }^{280} \mathrm{U}$. The data in Table A-II are for depleted uranium, and thus assuming an isotopic ratio of 0.0072 for the DNA. method is not valid.

In an attempt to substantiate the heterogeneity of soil sample aliquots, we completely analyzed three samples $(78.00854,-855$, and -856$)$ by the DNA method. These results are presented in Tables III and IV for ease in comparing the results. The wide range of aliquot concentrations indicates the great deal of variability between aliquots. LASL sample 78.00854 has a particularly wide range (6.3-1600), although the other two samples have ranges of 161 and 194. The poor agreement between the EAFB procedure and the weighted average of the DNA analyses is due to the samples' containing depleted uranium. Thus, we would expect the DNA analysis to give much lower concentrations than gre actually present.

\section{August 21, 1978, EAFB Soil Samples}

The data in Table A-III are analyses of 52 soil samples collected 21 Augist 1978 on ADTC Test Area C-64 to establish a base-line uranium con-
RESULTS OF THE WILCOXON SIGNED RANK TEST OF THE RATIOS OF THE THREE ANALYTICAL METHODS FROM THE 5 MAY 1978 SOIL DATA

\begin{tabular}{|c|c|c|c|}
\hline Ratıo & $\begin{array}{c}\text { Observations } \\
\text { Less } \\
\text { Than } 1\end{array}$ & $\begin{array}{c}\text { Observations } \\
\text { Greater } \\
\text { Than I }\end{array}$ & $\begin{array}{c}\text { Test } \\
\text { Significance }\end{array}$ \\
\hline IENA/EAFB & 26 & 8 & 0.008 \\
\hline DNA/EAFB & 24 & 10 & 0.146 \\
\hline IEN. A/DNA & 13 & 21 & 0.001 \\
\hline
\end{tabular}

centration for the area before its first use. EAFB samples 1-17, 2-16, and 3-17 were controls. DNA and IENA analyses were conducted on different 2-g aliquots taken from each soil sample. The uncertainties listed in Table A-III represent the counting errors.

The IENA technique varies greatly at the 1-ppm concentration level, and thus the DNA analysis should be considered the more reliable of the two presented. The means and standard deviations of the samples in Table A-III are: IENA, $0.88 \pm 0.45$; DNA, $0.64 \pm 0.17$.

These data are plotted in Fig. 6. Except for three high values of IENA, the plot suggests good agreement between the DNA and IENA results, hut the vilues vary greatly from sample to sample. The nlotted data suggest that the expected ratio of the tw analysis techniques is close to 1 , but after we tested the ratio statistically with the Wilcoxon signed rank test, we rejected the hypothesis that it was equal to 1 $(P=0.0002)$. Of the 52 values, only 19 were less than 1. The mean of the ratios is 1.44 , with standard deviation 0.87 . Thus, we conclude that IENA and DNA are not measuring the same quantities at these low background concentrations.

\section{SUMMARY AND CONCLUSIONS}

Comparison of the instrumental measurements of LASL E-F Site soil uranium obtained by the portable phoswich detector with the 1976 results of soil uranium messured by chemical analytical methods indicates good agreement between the two surveys. We believe the phoswich instrument may be good for field use to survey soil uranium concentretions. Further studies will be required at sites where the 
TABLE III

TOTÁL ANALYSIS OF THREE SAMPLES OF EAFB SOIL BY THE DNA METHOD

\begin{tabular}{|c|c|c|c|c|c|c|}
\hline & \multicolumn{2}{|c|}{78.00854} & \multicolumn{2}{|c|}{78.00855} & \multicolumn{2}{|c|}{78.00856} \\
\hline & $\begin{array}{c}\mathrm{U} \\
\text { (ppm) }\end{array}$ & $\begin{array}{c}\text { Sample } \\
\text { Weight } \\
\text { (g) } \\
\end{array}$ & $\begin{array}{c}\mathrm{U} \\
(\mathbf{p p m}) \\
\end{array}$ & $\begin{array}{c}\text { Sample } \\
\text { Weight } \\
\text { (B) } \\
\end{array}$ & $\underset{\text { (ppm) }}{\mathbf{U}}$ & $\begin{array}{c}\text { Sample } \\
\text { Weight } \\
\text { (g) }\end{array}$ \\
\hline & 6.3 & 2.00 & 210 & 2.00 & 250 & 2.00 \\
\hline & 85 & 2.00 & $62^{a}$ & 3.99 & $61^{\circ}$ & 5.04 \\
\hline & $28^{\mathrm{a}}$ & 4.34 & $49^{a}$ & 4.61 & $59^{a}$ & 4.83 \\
\hline & $26^{a}$ & 4.30 & $56^{\circ}$ & 5.06 & $56^{\circ}$ & 4.32 \\
\hline & $26^{\mathrm{a}}$ & 4.47 & 124 & 6.10 & 131 & 5.94 \\
\hline & 56 & 5.88 & 124 & 5.88 & 141 & 5.39 \\
\hline & 51 & 5.97 & 80 & 6.24 & 1.11 & 5.83 \\
\hline & 51 & 6.12 & 109 & 6.12 & 150 & 4.83 \\
\hline & 63 & 5.97 & 113 & 6.03 & 112 & 5.84 \\
\hline & 48 & 5.75 & 96 & 6.20 & 105 & 6.27 \\
\hline & 1600 & 5.94 & 121 & 6.06 & 154 & 6.13 \\
\hline & 54 & 5.94 & 130 & 6.48 & 119 & 5.94 \\
\hline & 50 & 5.79 & 159 & 2.79 & 117 & 5.96 \\
\hline & 60 & 3.33 & $\cdots$ & $\ldots$ & --- & $-\cdot-$ \\
\hline Total Weight & & 67.80 & & 67.56 & & 68.32 \\
\hline $\begin{array}{l}\text { Weighted Av } \\
\text { UConc }\end{array}$ & 221 & & 118 & & 131 & \\
\hline EAFB U Conc & 153 & & 390 & & 461 & \\
\hline
\end{tabular}

concentrations are as low as those observed at EAFB.

Comparisons of three different analytical techniques to measure uranium concentrations in soil indicate differences in the methods. Part of the lack of agreement between methods is explainable by the heterogeneity of aliquots taken from the same soil sample. However, there seems to be a basic dif- ference in what each of the three techniques measures.

\section{ACKNOWLEDGMENTS}

We appreciate the assistance of T. E. Hakonson, W. R. Hansen, and $D$. R. Dreesen in reviewing a preliminary draft of this report. 


\section{TABLE IV}

STEM AND LEAF DISPLAYS OF THE THREE SOIL SAMPLES COMPLETELY ANALYZED BY DNA*

\begin{tabular}{|c|c|c|c|c|c|}
\hline \multicolumn{2}{|c|}{78.00854} & \multicolumn{2}{|c|}{78.00855} & \multicolumn{2}{|c|}{78.00856} \\
\hline Stem & Leaf & Stem & Leaf & Ste!n & Leaf \\
\hline 0 & 6 & 0 & & 0 & \\
\hline 10 & & 10 & & 10 & \\
\hline 20 & 668 & 20 & & 20 & \\
\hline 30 & & 30 & & 30 & \\
\hline 40 & 8 & 40 & 9 & 40 & \\
\hline 50 & 01146 & 50 & 6 & 50 & 69 \\
\hline 60 & 03 & fi) & 2 & 60 & 1 \\
\hline 70 & & 70 & & 70 & \\
\hline 80 & 5 & 80 & 0 & 80 & \\
\hline 90 & & 90 & 6 & 90 & \\
\hline 100 & & 100 & 9 & 100 & 5 \\
\hline 110 & & 110 & 3 & 110 & 1279 \\
\hline 120 & & 120 & 144 & 120 & \\
\hline 130 & & 130 & 0 & 130 & 1 \\
\hline 140 & & 140 & & 140 & 1 \\
\hline 150 & & 150 & 9 & 150 & 02 \\
\hline 160 & & 160 & & 160 & \\
\hline 170 & & 170 & & 170 & \\
\hline 180 & & 180 & & 180 & \\
\hline 190 & & 190 & & 190 & \\
\hline 200 & & 200 & & 200 & \\
\hline 210 & & 210 & 0 & 210 & \\
\hline 220 & & 220 & & 220 & \\
\hline 230 & & 230 & & 230 & \\
\hline 240 & & 240 & & 240 & \\
\hline 250 & & 250 & & 250 & 0 \\
\hline 1600 & 0 & 1600 & & 1600 & \\
\hline
\end{tabular}

\begin{tabular}{|c|c|c|c|}
\hline Statistic & 78.00854 & 78.00855 & 78.00856 \\
\hline $\mathbf{n}$ & 14 & 13 & 13 \\
\hline Median & 51 & 113 & 117 \\
\hline Mean, $\bar{x}$ & 157.45 & 110.23 & 120.46 \\
\hline Standard Deviation, s & 415.65 & 44.12 & 50.98 \\
\hline Coefficient of Variation, $s / \overline{\mathbf{x}}$ & 2.64 & 0.40 & 0.42 \\
\hline
\end{tabular}

Example of how to read: the row 120|144 in the 78.00855 column represents three concentrations whose leaf digits are 1, 4, and 4; that is, the three concentrations are 121,124 , and 124 . 


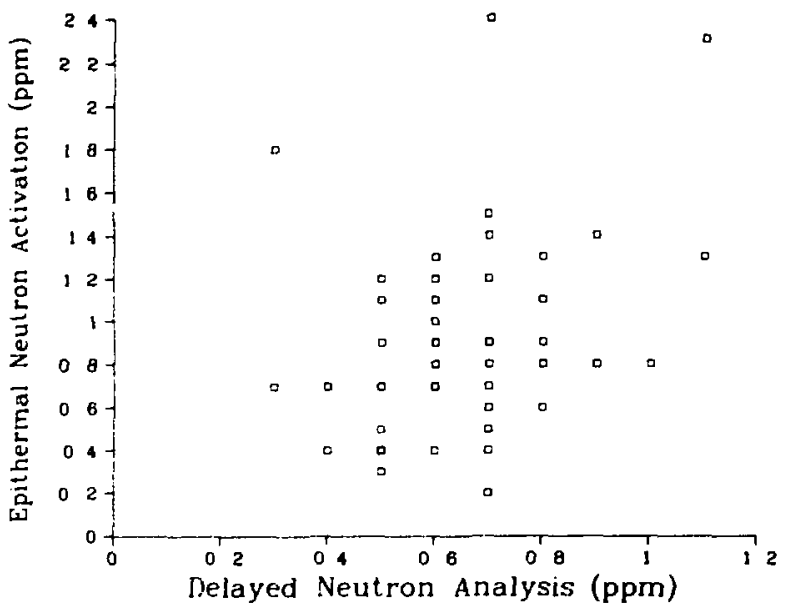

Fig. 6.

Comparison of the results of the IENA and DNA analytical techniques for determining uranium concentration in 21 August 1978, ADTC Test Area C-64, base-line soil samples.

\section{REFERENCES}

1. W. C. Hanson and F. R. Miera, Jr., "Long-Term Ecological Effects of Exposure to Uranium, "Los Alamos Scientific Laboratory report LA.6269 (July 1976).

2. W. C. Hanson and F. R. Miera, Jr., "Continued Studies of Long-Term Ecological Effects of Exposure to Uranium," Los Alamos Scientific Laboratory report LA-6742 (AFATL-TR-77-35) (June 1977).

3. W. C. Hanson and F. R. Miera, Jr., "Further Studies of Long-Term Ecological Effects of Exposure to Uranium," Los Alamos Scientific Laboratory report LA-7162 (AFATL-TR-78-8) (July 1978).
4. E. S. Gladney, J. W. Owens, and J. W. Starner, "Simultaneous Determination of Uranium and Thorium in Ores by Instrumental Epithermal Neutron Activation Analysis, "Anal. Chim. Acta 104, 121-127 (1979).

5. C. J. Umbarger and M. A. Wolf, "A Battery Operated Portable Phoswich Detector for Field Monitoring of Low Levels of Transuranic Contaminants," Nucl. Instrum. Methods 155, 453457 (1978).

6. G. R. Price, R. J. Ferretti, and S. Schwartz, "Fluorophotometric Determination of Uranium," Anal. Chem. 25, 322-331 (1953).

7. J. W. Owens, "Fluorometric Determination of Uranium in Environmental Materials," Los Alamos Scientific Laboratory report LA-6338MS (May 1976).

8. D. Landis and F. S. Goulding, "The Application of Pulse-Shape Discrimination to Separating Phototube Noise Pulse from Scintillation Pulses," Nucl. Instrum. Methods 33, 303-305 (1965).

9. W. G. Cochran, Sampling Techniques (Wiley \& Sons, Inc., New York, 1963), pp. 327-354.

10. E. S. Gladney, W. K. Hensley, and M. M. Minor, "Comparison of Three Techniques for the Measurement of Depleted Uranium in Soils," Anal. Chem. 50, 652-653 (1978).

11. M. Hollander and D. A. Wolfe, Nonparametric Statistical Methods (Wiley \& Sons, Inc., New York, 1973), pp. 26-33. 
Apprivix

DETEKMINATJON OF CRANILM IN SOILS

TARLE, A-I

ANALYTICAL RFSULTS FUF RAFB SOI! SAMPLES

COLLECTEID I JANUARY 197K

\begin{tabular}{|c|c|c|}
\hline FAFB No. & $\begin{array}{l}\text { HAFH Result } \\
(\mathrm{ppm}=(\mathbf{g} / \mathrm{h})\end{array}$ & $\begin{array}{l}\text { I.ASI. Hesult } \\
\left(\mathrm{ppm}=\mu_{\mathrm{K}} / \mathrm{g}\right)\end{array}$ \\
\hline 1,01010$)$ & $f(x) x:$ & $5 x(x) \pm 1 f(x)$ \\
\hline$(1.1)$ & $94(K)$ & $4: 3(x) \pm 940$ \\
\hline 1.7 & 7122 & $14(x)=3(4)$ \\
\hline 1.9 & .329 & $312 \pm 45$ \\
\hline 22 & 97 & $35 \pm 5$ \\
\hline 1.1 & 32 & $17 \pm 1$ \\
\hline 2.15 & 16 & $14 \pm 1$ \\
\hline Munge ('untrol ! & (1) & $(1.9 \pm 0.3$ \\
\hline Hange: (ontrol 2 & $\therefore$ & $0 . x \pm 11.3$ \\
\hline
\end{tabular}


TABLEF A-II

\section{ANAIYTICAL, RESLITS FOK EAFB SOLL SAMPLES COLLECTED 5 MAY 1978}

LASI Results

fafB No. LasL No.

$\begin{array}{ccc}\text { EAFB Resule } & \text { DNA } & \text { IENA } \\ (\mu \bar{B} / B) & \left(\mu B^{\prime} / B\right) & (\mu B / B)\end{array}$

0.0
1.1
1.3
1.5
1.7
1.9
1.11
1.13
1.15
1.15 coontroll
1.19 conteril)

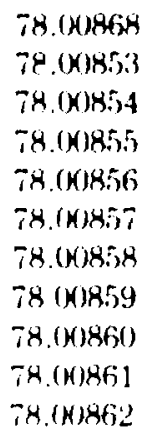

170

$25 \pm 1^{\circ} \quad 173$

$188 \pm 15$

$20 \pm 4$

$150 \pm 4$

$27 \pm 1$

$56 \pm 6$

$59 \pm 2$

$9.6 \pm 0.4$

81

$370 \pm 28$

$44.3 \pm 25$

26

$5.1 \pm 0.1$

$5.9 \pm 0.1$

6.3

$1(x)$

$32 \pm 2$

210

250

13

297

$0.87 \pm 0.12$

$0.72 \pm 0.02$

40

25

1

$<1$

210

NI

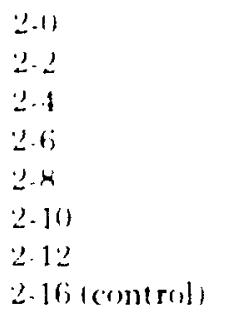

Th.0)1866.3

$4: 35$

TR. (n)'R6.4

126

TR.(1) 1065.5

45

is.ones66;

TR. 14065

78. 608659

ingoger:

7R.0(1)

$99 \pm 13$

370

$17 \pm 2$

94

$8.6 \pm 0.5 \quad 125$

$5.6 \pm 1.1 \quad 28$

8

$2.0 \pm 0.5$

6.3

$1.3 \pm 0.4$

ND

$2.0 \pm 0.2 \quad 30$

$3: 3$

$1.2 \pm 0.2$

Ni)

$3-1$

78.100872

78.0087:3

78.00874

78.00875

78.00876

78.00877

78.00878

78.001879

1
75
$<1$
18
1
$<1$
4
28

$1.8 \pm 0.1 \quad N D$

$9.0 \pm 0.8 \quad 45$

$1.6 \pm 0.1 \quad$ ND

$1.5 \pm 0.2 \quad 92$

$1.4 \pm 0.1 \quad$ ND

$1.3 \pm 0.1 \quad$ ND

$1.6 \pm 0.2 \quad 4.8$

$3-15$

78.00880

78.00881

78.00882

78.00883

78.00884

$5.8 \pm 0.5$

40

$\begin{array}{ll}4-0 & 78.00880 \\ 4-2 & 78.00881 \\ 4-4 & 78.00882 \\ 4-6 & 78.00883 \\ 4-8 & 78.00884 \\ 4-10 & 78.00885 \\ 4-12 & 78.00886\end{array}$

8

$2.2 \pm 0.5 \quad 14$

$<1$

$2.0 \pm 0.1 \quad$ ND

1 i 0

$3.1 \pm 0.7$

6

$<1$

$1.2 \pm 0.1$

$2.3 \pm 0.2$

ND

37

$1.3 \pm 0.3$

5

$<1$

$1.4 \pm 0.1$

ND

$<1$

ND

Lincertainty represents the standard deviation of two analyses for EAFB results and three analyses for DNA results.

'ND means nondetected. 
TABLE A-III

\section{ANALYTICAL RESLLTS FOR EAFB SOIL SAMPLES COLLECTED 21 AUGUST 1978 AT TEST AREA C-64}

\begin{tabular}{|c|c|c|c|c|c|c|c|}
\hline EAFB No. & LASL No. & $\begin{array}{l}\text { IENA } \\
\text { (ppm) }\end{array}$ & $\begin{array}{c}\text { DNA } \\
\text { (ppm) }\end{array}$ & EAFB No. & LASL No. & $\begin{array}{l}\text { IENA } \\
\text { (ppm) }\end{array}$ & $\begin{array}{c}\text { DNA } \\
\text { (ppm) }\end{array}$ \\
\hline $0-0$ & 78.00754 & $0.7 \pm 0.3$ & $0.3 \pm 0.2$ & $\begin{array}{l}3-15 \\
3-17 \text { (control) }\end{array}$ & $\begin{array}{l}78.00780 \\
78.00781\end{array}$ & $\begin{array}{l}1.2 \pm c .2 \\
2.4 \pm 0.3\end{array}$ & $\begin{array}{l}0.7 \pm 0.2 \\
0.7 \pm 0.2\end{array}$ \\
\hline $1-1$ & 78.00755 & $1.3 \pm 0.3$ & $0.8 \pm 0.2$ & & & & \\
\hline $1-3$ & 78.00756 & $0.7 \pm 0.2$ & $0.7 \pm 0.2$ & $4-0$ & 78.00782 & $1.0 \pm 0.2$ & $0.6 \pm 0.2$ \\
\hline 1.5 & 78.00757 & $0.4 \pm 0.2$ & $0.4 \pm 0.2$ & $4 \cdot 2$ & 78.0078 .3 & $0.4 \pm 0.1$ & $0.6 \pm 0.2$ \\
\hline $1-7$ & 78.00758 & $0.8 \pm 0.3$ & $0.6 \pm 0.2$ & $4-4$ & 78.00784 & $1.1 \pm 0.2$ & $0.8 \pm 0.2$ \\
\hline $1-9$ & 78.00759 & $1.4 \pm 0.4$ & $0.7 \pm 0.2$ & $4-6$ & 78.00785 & $0.7 \pm 0.1$ & $0.6 \pm 0.2$ \\
\hline $1-11$ & 78.00760 & $0.4 \pm 0.2$ & $6.7 \pm 0.2$ & $4-8$ & 78.00786 & $0.4 \pm 0.1$ & $0.5 \pm 0.2$ \\
\hline $1-13$ & 78.00761 & $1.2 \pm 0.2$ & $0.6 \pm 0.2$ & $4 \cdot 10$ & 78.00787 & $0.7 \pm 0.1$ & $0.6 \pm 0.2$ \\
\hline 1.15 & 78.00762 & $1.4 \pm 0.5$ & $0.9 \pm 0.2$ & $4-12$ & 78.00788 & $0.7 \pm 0.1$ & $0.5 \pm 0.2$ \\
\hline $1-17$ (control) & 78.0076 .3 & $1.1 \pm 0.1$ & $0.5 \pm 0.2$ & $4 \cdot 14$ & 78.00789 & $0.9 \pm 0.1$ & $0.5 \pm 0.2$ \\
\hline $2 \cdot 0$ & 78.00764 & $1.3 \pm 0.3$ & $1.1 \pm 0.2$ & $5-1$ & 78.00790 & $0.4 \pm 0.1$ & $0.5 \pm 0.2$ \\
\hline $2-2$ & 78.00765 & $0.9 \pm 0.3$ & $0.8 \pm 0.2$ & $5-3$ & 78.00791 & $0.8 \pm 0.2$ & $0.8 \pm 0.2$ \\
\hline $2-4$ & 78.00766 & $1.5 \pm 0.5$ & $0.7 \pm 0.2$ & $5-5$ & 78.00792 & $0.9 \pm 0.2$ & $0.6 \pm 0.2$ \\
\hline $2-6$ & 78.00767 & $0.8 \pm 0.3$ & $0.9 \pm 0.2$ & $5-7$ & 78.00793 & $0.7 \pm 0.1$ & $0.4 \pm 0.2$ \\
\hline $2-8$ & 78.00768 & $1.8 \pm 0.3$ & $0.3 \pm 0.2$ & $5-9$ & 78.00794 & $0.8 \pm 0.2$ & $0.7 \pm 0.2$ \\
\hline $2-10$ & 78.00769 & $1.3 \pm 0.3$ & $0.6 \pm 0.2$ & $5-11$ & 78.00795 & $0.9 \pm 0.2$ & $0.6 \pm 0.2$ \\
\hline $2-12$ & 78.00770 & $0.4 \pm 0.1$ & $0.5 \pm 0.2$ & $5 \cdot 13$ & 78.00796 & $0.9 \pm 0.2$ & $0.7 \pm 0.2$ \\
\hline $2-14$ & 78.00771 & $0.8 \pm 0.2$ & $0.6 \pm 0.2$ & $5-15$ & 78.00797 & $0.3 \pm 0.1$ & 0.5 t. 0.2 \\
\hline $2-16$ (control) & 78.00772 & $0.8 \pm 0.3$ & $0.8 \pm 0.2$ & & & & \\
\hline & & & & $6-0$ & 78.00798 & $0.5 \pm 0.1$ & $0.7 \pm 0.2$ \\
\hline $3-1$ & 78.00773 & $2.3 \pm 0.3$ & $1.1 \pm 0.2$ & $6-2$ & 78.00799 & $0.6 \pm 0.1$ & $0.7 \pm 0.2$ \\
\hline $3-3$ & 78.00774 & $0.4 \pm 0.1$ & $0.5 \pm 0.2$ & $6-4$ & 78.00800 & $0.8 \pm 0.2$ & $1.0 \pm 0.2$ \\
\hline $3-5$ & 78.00775 & $0.9 \pm 0.2$ & $0.7 \pm 0.2$ & $6-6$ & 78.00801 & $0.4 \pm 0.1$ & $0.5 \pm 0.2$ \\
\hline $3-7$ & 78.00776 & $0.7 \pm 0.2$ & $0.4 \pm 0.2$ & $6-8$ & 78.00802 & $0.7 \pm 0.1$ & $0.5 \pm 0.2$ \\
\hline $3-9$ & 78.00777 & $1.2 \pm 0.2$ & $0.5 \pm 0.2$ & $6-10$ & 78.00803 & $0.7 \pm 0.1$ & $0.6 \pm 0.2$ \\
\hline $3-11$ & 78.00778 & $0.2 \pm 0.2$ & $0.7 \pm 0.2$ & $6-12$ & 78.00804 & $0.5 \pm 0.1$ & $0.5 \pm 0.2$ \\
\hline $3-13$ & 78.00779 & $1.1 \pm 0.2$ & $0.6 \pm 0.2$ & $6-14$ & 78.00805 & $0.6 \pm 0.1$ & $0.8 \pm 0.2$ \\
\hline
\end{tabular}




\section{DIST RIBUTION}

AUL/LSE 71.249

Maxwell AFB, AL 36112

ASD/ENFEA

Wright-Patiers on AFB, OH 45433

HQ USAF/SAMI

Bolling, AFB, DC 23332

OO-ALC/MMWMP

Hill AFB, UT 84406

AFIS/INT

Washington, DC 20330

HQ TAC/DRA

Langley ArD, VA 23665

TAC/INAT

Langley AFB, VA 23665

ASD/ENESH/S. Johns

Wright-Patterson AFB, OH 45433

US Army TRADOC Sys

Analysis Activity

Attn: ATAA-SL (Tech Lib)

White Sands Msl Range, NM 88002

HQ USAFE/DOQ

APO New York 09012

HO PACAF/DOOFO

Hickham AFB, HI 96853

ASD/XRP

Wright-Patterson AFB, OH 45433

COMIPAC/1-232

Box 38, Camp H.M.

Smith, HI 96861

AFATL/DLODL

Eglin AFB, FL 32542

DDR\&E (Tech Lib)

Rm 3E1014

Pentagon

Washington, DC 20301

USAFA/DFCBS

USAF Academy, CO 84406

Dugway Prov Gd (Tech Lib)

Dugway, UT 84406

\section{AFLC/MMNO}

Hill AFB, UT 84406

SAAMA/SFQT

Keily AFB, TX 78241

\author{
AFSC/SDW \\ Andrewe AFB, \\ Washington, DC . 20334 \\ HQ USAF/RDP \\ Washington, DC 20330 \\ AFSC/DEV \\ Andrews AFB \\ Wasington, DC 20330 \\ DDR\&E (Env \& Life Sciences) \\ Rm 3E 1014 \\ Pentigon \\ Washington, DC 20301 \\ Chemical Systems Lab \\ DRDAR CLJ-L (Tech Lib) \\ Aberdeen Prov Gd, MD 21010 \\ USAF (Eתv Health Lab) \\ Kelly AFB, TX 78241 \\ NWC Env Eng (Mr. Ouimette) \\ China Lake, CA 93555
}

AMD/RD

Brooks AFB, TX 78235

AMRL/THE (Dr. London)

Wright-Patterson AFB, OH 45433

AMRL/THT (DI. Back)

Wright-Patterson AFB, OH 45433

ADTC/CSV

EGLDN AFB, FL 32542

ADTC/SGPE

Eglin AFB, FL 32542

Det 1 (CEEDO/EC)

Tyndall AFB, FL 32401

AFLC/DS

Hill AFB, UT 84406

US Army Natick Lab

Natick, MA 07162

ADTC/DLV

Eglin AFB, FL 32542

Accessions Div DDC-DDA

Cameron Station

Deseret Test Center/

Tech Lib, Dugway Prov Gd

Dugway, UT 84022 
Naval Weapons Cenier!

Tech Lib, Chim Lake, CA 93555

AEDC/DEE

Amold AFS, TN 37389

AFCEC/EO

Tyndali AFB, FL 3240 t

Commander, ARRADOOM

Attn: DRDAR-SCM-P

(Dr. Bloore)

Dover, NJ 07801

Baftelle Pacific Northwest

Lob (Aton: Dr. Wayne Hanson)

Richland, WA 99352

1035 TCHOG/TRE

(D. Colbns)

Patrick AFB, FL 32925 